\title{
Networking for applied field epidemiology - Eastern Mediterranean Public Health Network (EMPHNET) Conference 2011
}

\author{
M. Al Nsour ${ }^{7}$ and R. Kaiser ${ }^{2}$
}

$$
\text { مُشَابَكَة الوبائيات الميدانية التطبيقية - مؤتمر شبكة إقليم شرق المتوسط للصحة العمومية لعام } 2011
$$

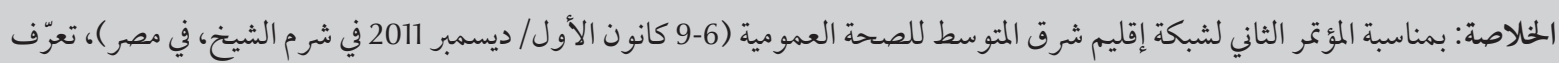

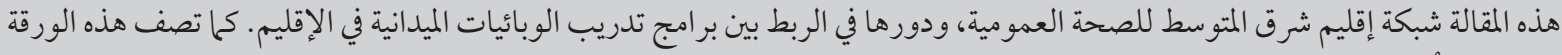

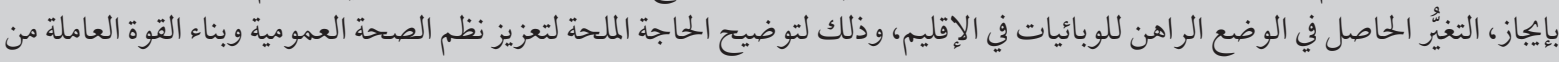$$
\text { اختصاصيِّي الوبائيات. }
$$

ABSTRACT On the occasion of the second Eastern Mediterranean Public Health Network (EMPHNET) conference that was held from 6-9 December 2011 in Sharm Al Sheikh, Egypt, this article introduces EMPHNET and its role to link Field Epidemiology Training Programs (FETP) in the region. The paper briefly describes the changing epidemiology situation in the region to illustrate the urgent need to strengthen public health systems and to build up the epidemiologist workforce.

Nouer des liens en faveur de l'épidémiologie de terrain appliquée : le rôle de la conférence 2011 du Réseau de la Méditerranée orientale pour la santé publique

RÉSUMÉ À l'occasion de la deuxième conférence du Réseau de la Méditerranée orientale pour la santé publique qui s'est tenue du 6 au 9 décembre 2011 à Charm El Cheikh (Égypte), l'article présente ce réseau et son rôle dans l'établissement de liens entre les programmes de formation en épidémiologie de terrain au niveau régional. II décrit brièvement l'évolution de la situation de l'épidémiologie dans la région pour illustrer la nécessité urgente de renforcer les systèmes de santé publique et de développer les ressources humaines en épidémiologie. 


\section{Introduction}

The Eastern Mediterranean Public Health Network (EMPHNET) is a regional network that is linking Field Epidemiology Training Programs (FETPs) in the Middle East and North Africa Region (MENA) [1]. FETPs are applied epidemiology programmes that help countries to improve and strengthen their public health system and infrastructure by building up a cadre of well-trained epidemiologists. The second EMPHNET conference was held from 6-9 December 2011, in Sharm Al Sheikh, Egypt [2] and allowed FETP residents to present their work and stimulated debate about major public health issues in the region. In this communication, we discuss the importance of FETPs against the background of a changing population and health situation in the MENA region.

\section{The concept of Field Epidemiology Training Programs}

The FETP is a 2-year, full-time training and service programme, which involves classroom instruction in a variety of epidemiology- and public health-related subjects, and field assignments including disease outbreak investigations and use of disease surveillance systems for decision-making. The programme is based on the U.S. Centers for Disease Control and Prevention's (CDC) epidemic intelligence service, which started in 1951. In 1975 the Canadians started their programme in consultation with $\mathrm{CDC}$ [3], and since then the number of programmes has increased dramatically. As of August 2010, there were 52 FETPs worldwide covering 66 countries (some are regional programmes) [4]. The concept of FETPs has further evolved in recent years with the development of a standard curriculum including defined core competencies and proficiency levels [5]. In the MENA region, the first FETP was started in 1989 in Saudi Arabia, followed by Egypt (1993), Jordan (1998) and Pakistan (2006). New FETPs have recently been established in Iraq (2010), Morocco (2010) and Yemen (2011). A new FETP is also in preparation in Afghanistan (Pakistan and Afghanistan are included here because they are part of EMPHNET).

\section{The EMPHINET conference - facing a changing epidemiology in the region}

To date, over 250 epidemiologists have graduated from the MENA FETP. However, much remains to be done if the number of trained epidemiologists is to be increased to a ratio of 1 per 200000 population [6].

The epidemiology in the region is characterized by increasing and ageing populations, half of them now living in urban areas (Table 1). The total fertility rate per woman has decreased from 5.5 in 1990 to 3.4 in 2009 but this is not enough to limit population growth. Given that there is a strong positive correlation between birth rates and child mortality [7], the successful reduction in under-5 mortality in the region from 100 deaths per 1000 live births in 1990 to 68 per 1000 live births in 2010 will help to stabilize population growth (Table 1); however, this is less than half of the Millennium Development Goal target for 2015 of 33 per 1000 live births [8]. Noncommunicable disease mortality is more than 3 times higher now than mortality from infectious and parasitic diseases (Table 1); however, emerging or re-emerging infectious diseases such as brucellosis [9] or dengue fever $[10,11]$ are of concern for the region. An epidemiological profile of Egyptian human H5N1 influenza virus cases was found that differs from other countries and raised the urgent need for prospective studies [12]. In face of the increasing relative importance of chronic diseases, behavioural changes demand our attention. In adults aged $\geq 20$ years, the prevalence of obesity (body mass index $\geq 30 \mathrm{~kg} / \mathrm{m}^{2}$ ) in 2008 was highest in the region for men in Kuwait [37.2\%, 95\% confidence interval (CI): $32.4 \%-42.3 \%]$ and Qa$\operatorname{tar}(30.8 \%, 95 \%$ CI: 26.6\%-35.6\%), and in women in Kuwait (52.4\%, 95\% CI:46.7\%-58.0\%) and Egypt (46.3\%, 95\% CI: 42.7\%-49.9\%) [13], indicating rapid changes in diets and lifestyles in the region [14]. One-third of men smoke and mortality from traffic accidents has not declined over time (Table 1). The proportion of the population with access to improved drinking-water sources and sanitation remains low in rural areas (Table 1). Environmental changes, including declining per capita water resources, loss of arable land, pollution-related problems, deteriorating coastal zones and vulnerable marine resources [15], will have an impact on health in the region. For example, annual renewable water resources per capita are expected to fall from 1997 levels of $1045 \mathrm{~m}^{3}$ per year to $740 \mathrm{~m}^{3}$ per year by 2015 [15]. Finally, recent political changes in the region have been accompanied by health impacts such as attacks against civilians and health facilities [16].

\section{Conclusion}

FETPs play an important role for health systems strengthening and workforce development and are more than ever needed to respond effectively to today's public health challenges. The recent EMPHINET conference of 2011 brought together epidemiologists and public health experts for scientific exchange and to improve networking and collaboration across the MENA region [17]. Workshops were held 


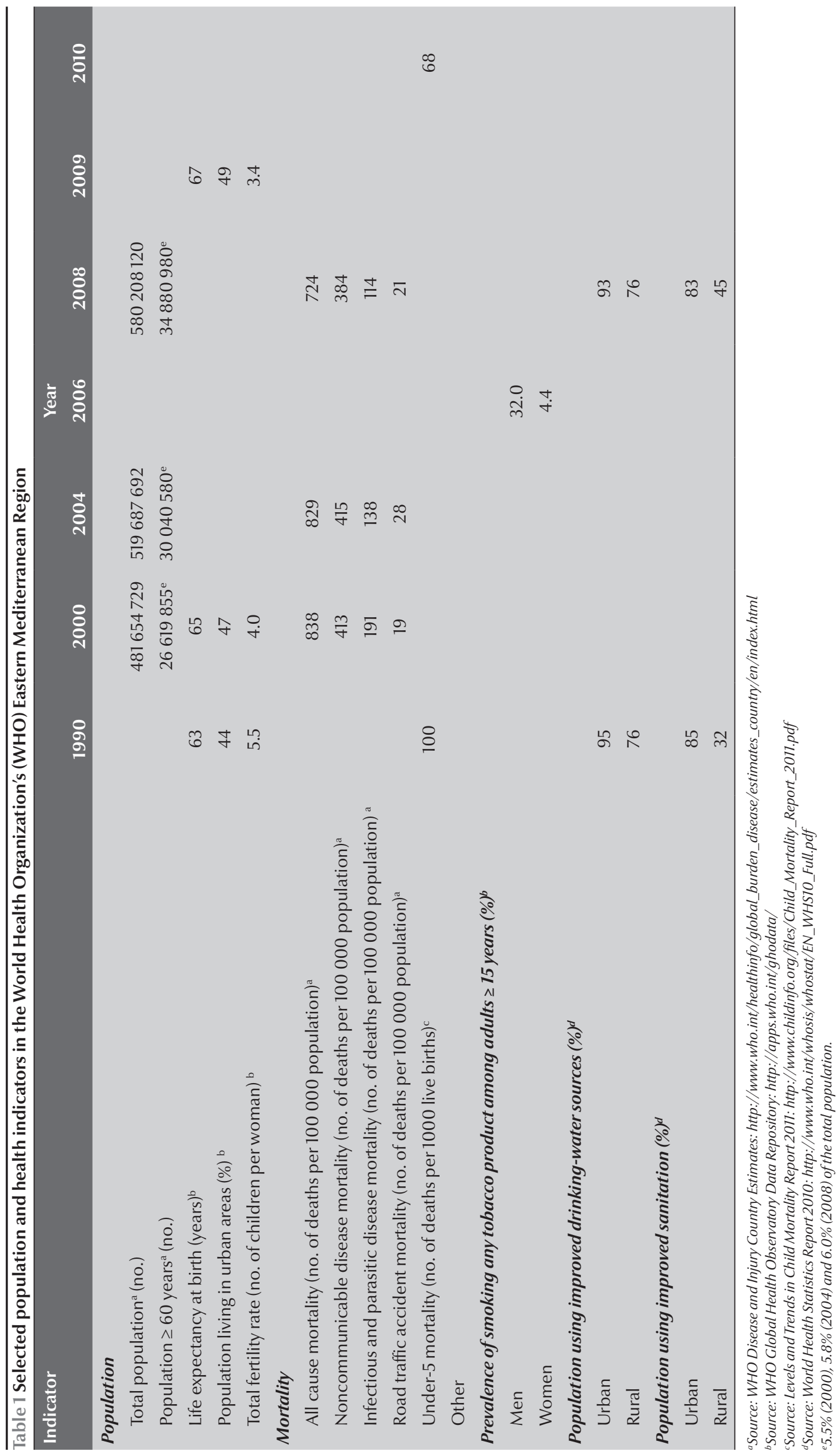


about noncommunicable diseases, epidemiological methods in emergencies, and ethics issues for the planning of and response to pandemics and other emergencies. Presentations included a variety of topics such as hepatitis B in pregnant women in Egypt, a
Chikungunya outbreak in Yemen, breast cancer in Jordan, and a Crimean Congo haemorrhagic fever outbreak in Afghanistan. The Eastern Mediterranean Health Journal will report on highlights and conclusions of the conference in an early issue of 2012.

\section{Author disclaimer}

The findings and conclusions in this manuscript are those of the authors and do not necessarily represent the views of the Centers for Disease Control and Prevention.

\section{References}

1. EMPHNET. The Eastern Mediterranean Health Network [website] (http://emphnet.net/WelcometoEMPHNET/tabid/87/ Default.aspx, accessed 29 September 2011).

2. EMPHNET. Regional Conference 2011, December 6-9, Egypt (http://conferences.tephinet.org/emphnet-2011, accessed 29 September 2011).

3. White ME et al. Partnerships in international applied epidemiology training and service, 1975-2001. American Journal of Epidemiology, 2001, 154:993-999.

4. Centers for Disease Control and Prevention (CDC). Global Health. Field Epidemiology Training Program (FETP) (http:// www.cdc.gov/globalhealth/fetp/, accessed 29 September 2011).

5. Traicoff DA et al. Replicating success: developing a standard FETP curriculum. Public Health Reports, 2008, 123(Suppl. 1):28-34.

6. Centers for Disease Control and Prevention (CDC). Minutes from the April 12, 2010 CDC Advisory Committee to the Director (http://www.cdc.gov/about/advisory/pdf/ACD_Minutes_04_12_10_Final.pdf, accessed 29 September 2011).

7. Rosenzweig MR, Schultz TP. Consumer demand and household production: the relationship between fertility and child mortality. American Economic Review, 1983, 73(2):38-42.

8. United Nations Children's Fund (UNICEF). Levels and trends in child mortality. Report 2011. UN Interagency group for child mortality estimation. New York, UNICEF, 2011 (http://www.childinfo.org/files/Child_Mortality_Report_2011.pdf, accessed 29 September 2011).

9. Brucellosis. Geneva, World Health Organization, 1999 (WHO Fact sheet N173) (https://apps.who.int/inf-fs/en/fact173.html, accessed 29 September 2011).

10. Yemen: Dengue fever spreading in south. IRIN news, 14 July 2010 (http://www.irinnews.org/report.aspx? reportid=89826, accessed 29 Sept 2011).
11. JelinekT. Trends in the epidemiology of dengue fever and their relevance for importation to Europe. Euro Surveillance, 2009, 14(25):19250 (http://www.eurosurveillance.org/ViewArticle. aspx?Articleld=19250, accessed 29 September 2011)

12. Kayali $\mathrm{G}$ et al. The epidemiological and molecular aspects of influenza H5N1 viruses at the human-animal interface in Egypt. PLoS ONE, 2011, 6:e17730 (http://www.plosone.org/ article/info:doi/10.1371/journal.pone.0017730, accessed 11 December 2011).

13. World Health Organization. Global Health Observatory Data Repository (http://apps.who.int/ghodata/, accessed 29 September 2011).

14. World Health Organization, Regional Office for the Eastern Mediterranean. Nutritional transition [website] (http://www. emro.who.int/nutrition/nutrition_transition.htm, accessed 29 September 2011),

15. World Bank. Environment Sector Brief Middle East and North Africa. http://web.worldbank.org/WBSITE/EXTERNAL/ COUNTRIES/MENAEXT/0,,contentMDK:20525954 pagePK: 146736 piPK:226340 theSitePK:256299,00.html, accessed 3 November 2011).

16. World Health Organization, Regional Office for the Eastern Mediterranean. [WHO condemns attacks against civilians and health facilities in Yemen] [Press release] (http://www.emro. who.int/pressreleases/2011/8-September-2011_ar.htm, accessed 29 September 2011) [In Arabic].

17. Leventhal A et al. Regional collaboration in the Middle East to deal with H5N1 avian flu. British Medical Journal, 2006, 333:856-858. 